\title{
Secret hiding places in the eye and beyond: what about after SARS-CoV-2 infection?
}

\author{
Thomas C. Erren ${ }^{1} \cdot$ Philip Lewis ${ }^{1}$
}

Received: 25 March 2021 / Revised: 25 March 2021 / Accepted: 28 April 2021 / Published online: 3 August 2021

(c) The Author(s) 2021

\section{Dear Editor:}

In a prospective study, Rokohl and colleagues looked into the possibility that SARS-CoV-2 may hide in the eyes of prescreened asymptomatic patients in a tertiary eye care center [1]. The authors explored this possibility in 1145 patients of whom none had any real-time reverse transcriptase-polymerase chain reaction (RT-PCR)-confirmed virus-positive result from nasopharyngeal swabs, suggesting that all study individuals were uninfected. Regarding conjunctival swabs, all tested eyes yielded virus-negative results. Clearly, this is important empirical information in regard to infection risks for ophthalmologists and medical staff in tertiary eye care centers, including the handling of human corneal donor tissue - always provided that patients or donors are not infected.

We compliment the authors for taking this initiative and call for research regarding hiding places of SARS-CoV-2 to be expanded: What about infected individuals, viz., COVID19 patients, survivors, or asymptomatic carriers, and virus material persistence in immune-privileged sites of the eye and elsewhere?

To exemplify why "secret" hiding sites in infected individuals may be(come) of interest, in 1967 a virus reservoir in sperm was proposed in the course of discovering the Marburg virus (MV) [2]. Careful observations had suggested that several diseased men's testes were also infected and abstaining from sex until further notice was recommended after hospital dismissal. Yet, after one MV patient left hospital and had intercourse with his wife, she developed symptoms and signs of Marburg disease. From the overall

Thomas C. Erren

tim.erren@uni-koeln.de

1 Institute and Policlinic for Occupational Medicine, Environmental Medicine and Prevention Research, University of Cologne, Kerpener Str. 61, 50938 Cologne, Germany evidence, it was concluded that the infection occurred via virus-containing ejaculate. In other words, an until then unappreciated (described as "unusual" [2]) spermatogeneous infection route from an MV reservoir which existed for almost 4 months was suggested. Regarding another filovirus, sexual transmission from a male survivor of Ebola virus disease [EVD] to his female partner was suspected in 2015 [3]. That Ebola virus RNA can persist many months after manifestation of disease [4] - in semen from an EVD survivor with pre-existing HIV infection it was detected 565 days after acute disease [5] - conveys that understanding virus clearance and remaining virus "potential" from immuneprivileged sites/organs is important for individuals and possibly public health [6].

Regarding SARS-CoV-2, investigating virus materials in semen of COVID-19 cases in acute and recovery phases yielded ambiguous results. The question of whether virus material may persist in the privileged immunity site of the testes remains open [7]. In contrast, regarding SARS-CoV-2 in the eye, Rokohl and colleagues pointed out that the virus was unambiguously detected in ocular tissues, tears, and conjunctival secretions of COVID-19 patients [1]. The key question of whether long(er)-term SARS-CoV-2 persistence in immune privileged sites such as in the eyes [8] of COVID19 survivors or asymptomatic carriers may hold long(er)term risks is empirically open and should be explored with targeted research $[9,10]$.

Author contribution Writing — Thomas C Erren \& Philip Lewis.

Funding Open Access funding enabled and organized by Projekt DEAL.

Data availability Not applicable.

Code availability Not applicable. 


\section{Declarations}

Conflict of interest The authors declare no competing interests.

Open Access This article is licensed under a Creative Commons Attribution 4.0 International License, which permits use, sharing, adaptation, distribution and reproduction in any medium or format, as long as you give appropriate credit to the original author(s) and the source, provide a link to the Creative Commons licence, and indicate if changes were made. The images or other third party material in this article are included in the article's Creative Commons licence, unless indicated otherwise in a credit line to the material. If material is not included in the article's Creative Commons licence and your intended use is not permitted by statutory regulation or exceeds the permitted use, you will need to obtain permission directly from the copyright holder. To view a copy of this licence, visit http://creativecommons.org/licenses/by/4.0/.

\section{References}

1. Rokohl AC, Grajewski RS, Wawer Matos PA, Koch HL, Dewald F, Klein F, Fätkenheuer G, Lehmann C, Cursiefen C, Heindl LM (2021) No secret hiding place? Absence of SARS-CoV-2 on the ocular surface of 1145 hospitalized patients in a pandemic area. Graefes Arch Clin Exp Ophthalmol 1-4. https://doi.org/10.1007/ s00417-021-05086-3

2. Martini GA, Schmidt HA (1968) Spermatogenic transmission of the "Marburg virus". (Causes of "Marburg simian disease"). Klin Wochenschr 46:398-400

3. Mate SE, Kugelman JR, Nyenswah TG, Ladner JT, Wiley MR, Cordier-Lassalle T, Christie A, Schroth GP, Gross SM, DaviesWayne GJ, Shinde SA, Murugan R, Sieh SB, Badio M, Fakoli L, Taweh F, de Wit E, van Doremalen N, Munster VJ, Pettitt J, Prieto K, Humrighouse BW, Ströher U, DiClaro JW, Hensley LE, Schoepp RJ, Safronetz D, Fair J, Kuhn JH, Blackley DJ, Laney AS, Williams DE, Lo T, Gasasira A, Nichol ST, Formenty P, Kateh FN, De Cock KM, Bolay F, Sanchez-Lockhart M, Palacios G (2015) Molecular evidence of sexual transmission of Ebola virus. N Engl J Med 373:2448-2454
4. Deen GF, Broutet N, Xu W, Knust B, Sesay FR, McDonald SLR, Ervin E, Marrinan JE, Gaillard P, Habib N, Liu H, Liu W, Thorson AE, Yamba F, Massaquoi TA, James F, Ariyarajah A, Ross C, Bernstein K, Coursier A, Klena J, Carino M, Wurie AH, Zhang Y, Dumbuya MS, Abad N, Idriss B, Wi T, Bennett SD, Davies T, Ebrahim FK, Meites E, Naidoo D, Smith SJ, Ongpin P, Malik T, Banerjee A, Erickson BR, Liu Y, Liu Y, Xu K, Brault A, Durski KN, Winter J, Sealy T, Nichol ST, Lamunu M, Bangura J, Landoulsi S, Jambai A, Morgan O, Wu G, Liang M, Su Q, Lan Y, Hao Y, Formenty P, Ströher U, Sahr F (2017) Ebola RNA persistence in semen of Ebola virus disease survivors - final report. N Engl J Med 377:1428-1437

5. Purpura LJ, Rogers E, Baller A, White S, Soka M, Choi MJ, Mahmoud N, Wasunna C, Massaquoi M, Kollie J, Dweh S, Bemah P, Ladele V, Kpaka J, Jawara M, Mugisha M, Subah O, Faikai M, Bailey JA, Rollin P, Marston B, Nyenswah T, Gasasira A, Knust B, Nichol S, Williams D (2017) Ebola virus RNA in semen from an HIV-positive survivor of Ebola. Emerg Infect Dis 23:714-715

6. Gross JV, Slanger TE, Cullen P, Erren M, Erren TC (2015) Stopping possible sexual transmission of filoviruses. Clin Infect Dis 60(12):1871-1872

7. Sharun K, Tiwari R, Dhama K (2020) SARS-CoV-2 in semen: potential for sexual transmission in COVID-19. Int J Surg $84: 156-158$

8. Varkey JB, Shantha JG, Crozier I, Kraft CS, Lyon GM, Mehta AK, Kumar G, Smith JR, Kainulainen MH, Whitmer S, Ströher U, Uyeki TM, Ribner BS, Yeh S (2015) Persistence of Ebola virus in ocular fluid during convalescence. N Engl J Med 372:2423-2427

9. Qu JY, Xie HT, Zhang MC (2021) Evidence of SARS-CoV-2 Transmission through the ocular route. Clin Ophthalmol 15:687-696

10. de Freitas Santoro D, de Sousa LB, Camara NOS, de Freitas D, de Oliveira LA (2021) SARS-COV-2 and ocular surface: from physiology to pathology, a route to understand transmission and disease. Front Physiol 12:612319

Publisher's note Springer Nature remains neutral with regard to jurisdictional claims in published maps and institutional affiliations. 